\title{
Chrozophorin: a new acylated flavone glucoside from Chrozophora tinctoria (Euphorbiaceae)
}

\author{
A. Delazar', B. Talischi', H. Nazemiyeh ${ }^{1}$, H. Rezazadeh ${ }^{1}$, L. Nahar', \\ S.D. Sarker ${ }^{3 *}$ \\ ${ }^{1}$ Pharmacognosy Laboratory, School of Pharmacy and Drug Applied Research Center, \\ Tabriz University of Medical Sciences, Tabriz, Iran, \\ ${ }^{2}$ Department of Chemistry, University of Aberdeen, Aberdeen AB24 3UE, Scotland, UK, \\ ${ }^{3}$ School of Biomedical Sciences, University of Ulster at Coleraine, Cromore Road, \\ Coleraine BT52 1SA, Co. Londonderry, Northern Ireland, UK
}

\begin{abstract}
RESUMO: "Crozoforina: uma nova flavona glicosilada e acetilada de Chrozophora tinctoria (Euphorbiaceae)". Análise das partes aéreas de Chrozophora tinctoria (Euphorbiaceae) através de HPLC preparativa com coluna de fase reversa produziu cinco glicosídeos de flavonóides, quercetina 3-O-rutinosídeo (1, rutina), acacetina 7-O-rutinosídeo (2), apigenina 7-O- $\beta$-D-[(6$p$-cumaroil)]-glicopiranosídeo (3), apigenina 7-O- $\beta$-D-glicopiranosídeo (4) e apigenina 7-O- $\beta$ D-[-(3,4-diidroxibenzoil)]-glicopiranosídeo (chamado crozoforina, 5), sendo o último um novo produto natural. As estruturas dessas substâncias foram inequivocamente elucidadas por análise de espectrofotometria de UV com o uso de reagentes de deslocamento, ESIMS, e técnicas de RMN 1D e 2D. A atividade de captura de radicais livres do extrato metanólico $\left(\mathrm{RC}_{50}=2,24 \times 10^{-1} \mathrm{mg} / \mathrm{mL}\right)$ bem como das substâncias isoladas (1-5) $\left(\mathrm{RC}_{50}=4,38 \times 10^{-3}, 2,26 \times 10^{-2}, 7,69 \times 10^{-4}, 8,71 \times 10^{-3} \mathrm{e}\right.$ $3,19 \times 10^{-4} \mathrm{mg} / \mathrm{mL}$, respectivamente) foram analisados pelo método DPPH.
\end{abstract}

Unitermos: Chrozophora tinctoria, Euphorbiaceae, flavonóide, flavona, glicosídeo, quercetina, apigenina, rutina, crozoforina, DPPH.

\begin{abstract}
Preparative reversed-phase HPLC analysis of the methanol extract of the aerial parts of Chrozophora tinctoria (Euphorbiaceae) yielded five flavonoid glycosides, quercetin 3-O-rutinoside (1, rutin), acacetin 7-O-rutinoside (2), apigenin 7-O- $\beta$-D-[(6- $p$-coumaroyl)]-glucopyranoside (3), apigenin 7-O- $\beta$-D-glucopyranoside (4) and apigenin 7-O- $\beta$-D-[6-(3,4-dihydroxybenzoyl)]glucopyranoside (named, chrozophorin, $\mathbf{5}$ ), the last one being a new natural product. The structures of these compounds were elucidated unambiguously by UV spectroscopic analyses using shift reagents, ESIMS, and 1D and 2D NMR spectroscopic techniques. The free-radical scavenging activity of the methanol extract $\left(\mathrm{RC}_{50}=2.24 \times 10^{-1} \mathrm{mg} / \mathrm{mL}\right)$ as well as the isolated compounds (1-5) $\left(\mathrm{RC}_{50}=4.38 \times 10^{-3} 2.26 \times 10^{-2}, 7.69 \times 10^{-4}, 8.71 \times 10^{-3}\right.$ and $3.19 \times 10^{-4} \mathrm{mg} / \mathrm{mL}$, respectively $)$ were assessed by the DPPH assay.
\end{abstract}

Keywords: Chrozophora tinctoria, Euphorbiaceae, flavonoid, flavone, glycoside, quercetin, apigenin, rutin, chrozophorin, DPPH.

\section{INTRODUCTION}

Chrozophora tinctoria (L.) A. Juss., an annual that is commonly known as 'dyer's-croton', 'giradol' or 'turnsole', belongs to the subtribe Chrozophorinae, tribe Chrozophoreae, subfamily Acalyphoideae and family Euphorbiaceae (GRIN Database, 2005). This species is native to a number of countries in Africa, (Algeria, Egypt, Libya, Morocco, Tunisia and Yemen) temperate and tropical Asia (Kuwait, Saudi Arabia, Afganistan, Iran, Iraq, Israel, Jordan, Lebanon, Syria, Turkey, Kazakhstan, Turkmenistan, India and Pakistan), and Europe (Ukraine, Albania, Bulgaria, Greece, Italy, Malta, France, former Yugoslavia, Portugal and Spain). Chrozophora tinctoria is well known for producing dye substances (Başlar;
Mert, 1999) and flavonoids (Hashim et al., 1990). Alkaloids, coumarins, chromones (Mohamed, 2001), flavonoids (Hashim et al., 1990), xanthones (Agrawal; Singh, 1988), diterpenoids (Mohamed et al., 1994, 1995) and phenylpropanoid glycosides (Mohamed, 2001) have previously been reported from a few other species of the genus Chrozophora. While, in the Iranian traditional medicine, $C$. tinctoria is used to treat warts, this plant has been used as an emetic, cathartic, and for the treatment of fever elsewhere (Phytochemical and Ethnobotanical Databases, 2005). As a part of our continuing search for natural antioxidants (Delazar et al., 2005, 2006; Nahar et al., 2005; Nahar; Sarker, 2005a,b; Sarker et al., 2005a,b; Kumarasamy et al., 2004), we now report on the isolation, structure determination, and free radical 
Table 1. ${ }^{1} \mathrm{H}$ NMR (coupling constant $J=\mathrm{Hz}$ in parentheses) and ${ }^{13} \mathrm{C}$ NMR data, and COSY interaction of compound 5.

\begin{tabular}{|c|c|c|c|}
\hline \multirow[t]{2}{*}{ Position } & \multicolumn{2}{|c|}{ Chemical shift $\delta$ in ppm } & \multirow[t]{2}{*}{${ }^{1} \mathrm{H}-{ }^{1} \mathrm{H}$ interaction obtained from COSY } \\
\hline & $\delta_{\mathbf{H}}$ & $\delta_{\mathbf{C}}$ & \\
\hline 2 & - & 162.2 & - \\
\hline 3 & $6.56 \mathrm{~s}$ & 102.3 & - \\
\hline 4 & - & 182.9 & - \\
\hline 5 & - & 158.4 & - \\
\hline 6 & 6.11 br s & 99.7 & $\mathrm{H}-8$ \\
\hline 7 & - & 165.0 & - \\
\hline 8 & 6.29 br s & 94.1 & H-6 \\
\hline 9 & - & 161.6 & - \\
\hline 10 & - & 106.2 & - \\
\hline 1 ' & - & 121.3 & - \\
\hline 2 ' & $7.53 \mathrm{~d}(8.4)$ & 128.3 & H-3, H-6' \\
\hline $3^{\prime}$ & $6.63 \mathrm{~d}(8.4)$ & 115.8 & H-2', H-5' \\
\hline $4^{\prime}$ & - & 161.6 & - \\
\hline $5^{\prime}$ & $6.63 \mathrm{~d}(8.4)$ & 115.8 & H-3'-H-6' \\
\hline $6^{\prime}$ & $7.53 \mathrm{~d}(8.4)$ & 128.3 & H-2', H-5' \\
\hline \multicolumn{4}{|c|}{ Glucose moiety } \\
\hline 1, & $5.17 \mathrm{~d}(7.0)$ & 102.3 & $\mathrm{H}-2{ }^{\prime}$ \\
\hline 2 ' & $3.20-3.80 *$ & 73.0 & - \\
\hline $3^{\prime \prime}$ & $3.20-3.80^{*}$ & 77.1 & - \\
\hline $4^{\prime}$, & $3.20-3.80^{*}$ & 70.8 & - \\
\hline 5, & $3.20-3.80 *$ & 74.7 & - \\
\hline $6 "$ & $4.42 \mathrm{~d}(12.15)$ & 64.3 & $\mathrm{H}-5$, \\
\hline \multicolumn{4}{|c|}{ Acyl moiety } \\
\hline 1, & - & 121.8 & \\
\hline $2,$, & $7.91 \mathrm{~d}(1.9)$ & 117.1 & H-3 ${ }^{,},$, H-6, \\
\hline 3, & - & 144.9 & H-2,", \\
\hline $4^{\prime \prime}$, & - & 150.1 & - \\
\hline 5, & $7.08 \mathrm{~d}(8)$ & 115.8 & - \\
\hline $6 "$, & $7.85 \mathrm{dd}(1.9,8)$ & 121.8, & $\mathrm{H}-2$ ', \\
\hline $7^{\prime \prime \prime}$ & - & 167.6 & \\
\hline
\end{tabular}

*Overlapped peaks; Spectra obtained in $\mathrm{MeOH}-\mathrm{d}_{4}$<smiles>[Z20]Oc1ccc(-c2oc3cc([R20])cc(O)c3c(=O)c2[R])cc1[R7]</smiles>

\begin{tabular}{lllll}
\hline Compound number & $\mathrm{R}$ & $\mathrm{R}$ & $\mathrm{R}{ }^{\prime}$ & $\mathrm{R}{ }^{\prime \prime}$ \\
\hline & & & & \\
$\mathbf{1}$ & $\mathrm{H}$ & Rutinosyloxy & $\mathrm{OH}$ & $\mathrm{H}$ \\
$\mathbf{2}$ & Rutinosyl & $\mathrm{H}$ & $\mathrm{H}$ & $\mathrm{Me}$ \\
$\mathbf{3}$ & $(6-O-p$-coumaroyl)-glucosyl & $\mathrm{H}$ & $\mathrm{H}$ & $\mathrm{H}$ \\
$\mathbf{4}$ & Glucosyl & $\mathrm{H}$ & $\mathrm{H}$ & $\mathrm{H}$ \\
$\mathbf{5}$ & $(6-O-3,4$-dihydroxybenzoyl)-glucosyl & $\mathrm{H}$ & $\mathrm{H}$ & $\mathrm{H}$ \\
\hline
\end{tabular}


scavenging activity of four known flavonoids (1-4) and a new acylated flavone glucoside, named chrozophorin $(\mathbf{5})$, from the aerial parts of $C$. tinctoria.

\section{MATERIAL AND METHODS}

\section{General}

UV spectra were obtained in $\mathrm{MeOH}$ using a Hewlett-Packard 8453 UV-vis spectrometer. NMR spectra were recorded in $\mathrm{CD}_{3} \mathrm{OD}$ on a Bruker $200 \mathrm{MHz}$ NMR Spectrometer $\left(200 \mathrm{MHz}\right.$ for ${ }^{1} \mathrm{H}$ and $50 \mathrm{MHz}$ for ${ }^{13} \mathrm{C}$ ) using residual solvent peak as internal standard. ESIMS analyses were performed on a Finnigan MAT95 spectrometer. HPLC separation was performed in a Shimadzu HPLC system. A Shim-Pak ODS column 10 $\mu \mathrm{m}, 250 \mathrm{~mm} \times 21.2 \mathrm{~mm}$ was used. Sep-Pak Vac $35 \mathrm{cc}$ $(10 \mathrm{~g}) \mathrm{C}_{18}$ cartridge (Waters) was used for pre-HPLC fractionation.

\section{Plant material}

The aerial parts of Chrozophora tinctoria were collected from Tabriz in eastern Azarbaijan province (situated in Iran) during May-June 2004, and the identity was confirmed by morphological characterisation in comparison with the herbarium specimen retained in the School of Pharmacy, Tabriz University of Medical Sciences. Also, a voucher specimen (BSAD0001) representing this collection has been generated in the herbarium of the Plant and Soil Science Department, University of Aberdeen, Scotland (ABD).

\section{Extraction, isolation and structure elucidation}

The dried and ground aerial parts of $C$. tinctoria $(100 \mathrm{~g})$ were Soxhlet-extracted, successively, with $n$ hexane, dichloromethane and methanol (1.1 L each). The $\mathrm{MeOH}$ extract $(2 \mathrm{~g})$ was subjected to Sep-Pack fractionation using a step gradient of $\mathrm{MeOH}$-water mixture (10:90, 20:80, 40:60, 60:40, 80:20 and 100:0). The preparative reversed-phase HPLC analysis (Shim-Pak ODS column $10 \mu \mathrm{m}, 250 \mathrm{~mm} \times 21.2 \mathrm{~mm}$; mobile phase: 0 to $50 \mathrm{~min}$ gradient 15 to $35 \% \mathrm{ACN}$ in water; flow-rate: $20 \mathrm{~mL} / \mathrm{min}$, detection at $248 \mathrm{~nm}$ ) of the $40 \%$ methanolic Sep-Pack fraction afforded quercetin 3-O-rutinoside (1, $4.7 \mathrm{mg}$, retention time: $14.1 \mathrm{~min}$ ). Similar purification (Shim-Pak ODS column $10 \mu \mathrm{m}, 250 \mathrm{~mm} \times 21.2 \mathrm{~mm}$; mobile phase: 0 to $50 \mathrm{~min}$ gradient 25 to $40 \% \mathrm{ACN}$ in water; flow-rate: $20 \mathrm{~mL} / \mathrm{min}$, detection at $248 \mathrm{~nm}$ ) of the $60 \%$ methanolic Sep-Pack fraction yielded acacetin 7-O rutinoside (2, $4.5 \mathrm{mg}$, retention time: $12.2 \mathrm{~min})$, apigenin 7 $O-\beta$-[(6-O-p-coumaroyl $)]$-glucoside $(3,3.8 \mathrm{mg}$, retention time: $18.9 \mathrm{~min})$, apigenin $7-O-\beta$-glucoside $(4,1.5 \mathrm{mg}$, retention time: $24.0 \mathrm{~min})$ and apigenin $7-O-\beta-\mathrm{D}-[6-(3,4-$ dihydroxybenzoyl)]-glucopyranoside (chrozophorin) (5, $2.5 \mathrm{mg}$, retention time: $36.1 \mathrm{~min}$ ). While compounds $\mathbf{1 - 4}$ were identified by direct comparison of its UV (in $\mathrm{MeOH}$ and using shift reagents), ESIMS, ${ }^{1} \mathrm{H}$ and ${ }^{13} \mathrm{C}$ NMR data with respective published data, the structure of compound 5 was elucidated by UV, ESIMS, ${ }^{1} \mathrm{H}-,{ }^{13} \mathrm{C}$ - and COSY NMR data analyses.

Apigenin 7-O-ß-D-[6-(3,4-dihydroxybenzoyl)]glucopyranoside (Chrozophorin) (5): Yellow amorphous solid. UV: $\lambda_{\text {max }}(\mathrm{MeOH}) \mathrm{nm}: 270,331$; NaOMe: 275 , $379 ;+\mathrm{AlCl}_{3}: 278,300,349,387 ;+\mathrm{AlCl}_{3}+\mathrm{HCl}: 279$, 299, 344, 386; + NaOAc: 275, 290, 374; + NaOAc + $\mathrm{H}_{3} \mathrm{BO}_{3}: 272,323 ;{ }^{1} \mathrm{H}-$ and ${ }^{13} \mathrm{C}$ NMR (Table 1). ESIMS: positive ion mode) $m / z 591[\mathrm{M}+\mathrm{Na}]^{+}$and negative ion mode) $m / z 567[\mathrm{M}-\mathrm{H}]$

\section{DPPH assay}

2,2-Diphenyl-1-picrylhydrazyl (DPPH), molecular formula $\mathrm{C}_{18} \mathrm{H}_{12} \mathrm{~N}_{5} \mathrm{O}_{6}$, was obtained from Fluka Chemie AG, Bucks. Quercetin was obtained from Avocado Research Chemicals Ltd, Shore road, Heysham, Lancs. The method used by Takao et al. (1994) was adopted with suitable modifications to our particular circumstance (Kumarasamy et al., 2002). DPPH (4 mg) was dissolved in $\mathrm{MeOH}(50 \mathrm{~mL})$ to obtain a concentration of $80 \mu \mathrm{g} / \mathrm{mL}$.

Qualitative assay: Test samples ( $\mathrm{MeOH}$ extract, and 1-5) were applied on a TLC plate and sprayed with DPPH solution using an atomiser. It was allowed to develop for $30 \mathrm{~min}$. The colour changes (purple on white) were noted.

Quantitative assay: The $\mathrm{MeOH}$ extract, and test compounds 1-5 were dissolved in $\mathrm{MeOH}$ to obtain a concentration of $1.0 \mathrm{mg} / \mathrm{mL}$. Dilutions were made to obtain concentrations of $5 \times 10^{-1}, 5 \times 10^{-2}, 5 \times 10^{-3}, 5 \times 10^{-}$ ${ }^{4}, 5 \times 10^{-5}, 5 \times 10^{-6} 5 \times 10^{-7}, 5 \times 10^{-8}, 5 \times 10^{-9}, 5 \times 10^{-10} \mathrm{mg} / \mathrm{mL}$. Diluted solutions $(1.00 \mathrm{~mL}$ each) were mixed with DPPH $(1.00 \mathrm{~mL})$ and allowed to stand for $30 \mathrm{~min}$ for any reaction to occur. The UV absorbance was recorded at 517 $\mathrm{nm}$. The experiment was performed in triplicate and the average absorption was noted for each concentration. The same procedure was followed for the positive standards (quercetin).

\section{RESULTS AND DISCUSSION}

RP-HPLC analysis of the methanol extract of the aerial parts of $C$. tinctoria afforded four known flavonoid glycosides, quercetin 3-O-rutinoside (1), acacetin 7-O-rutinoside (2), apigenin 7-O- $\beta$-D-[(6- $p$ coumaroyl)]-glucopyranoside (3), and apigenin 7-O- $\beta$ D-glucopyranoside (4), and a novel acylated flavonoid glucoside, apigenin 7- $O$ - $\beta$-D-[6-(3,4-dihydroxybenzoyl)]glucopyranoside (named, chrozophorin, 5). The known flavonoid glycosides were readily identified by direct comparison of the spectroscopic data with published data (Delazar et al., 2005; Mohamed, 2001; Markham; Geiger, 1993; Hashim et al., 1990; Agarwal; Raghunath, 
1989; Mabry et al., 1970). The structure of the new compound was elucidated on the basis of comprehensive spectroscopic analyses (e.g. UV, ESIMS, and 1D and 2D NMR).

Compound 5 exhibited characteristic UV absorption maxima for a flavone skeleton (Mabry et al., 1970). The results from the UV analysis using various shift reagents identified the apigenin structure with an $O$-substitution, other than $\mathrm{OH}$, at C-7 (Markham, 1982; Mabry et al., 1970). The ${ }^{1} \mathrm{H}$ NMR and ${ }^{13} \mathrm{C}$ NMR spectra of this compound (Table 1) also confirmed the presence of a flavone nucleus in this molecule (Markham; Geiger, 1993; Mabry et al., 1970). The ESIMS spectra of 1 revealed $[\mathrm{M}+\mathrm{Na}]^{+}$(positive ion mode) ion peak at $\mathrm{m} / z$ 591 , and $[\mathrm{M}-\mathrm{H}]^{-}$(negative ion mode) ion peak at $\mathrm{m} / z$ 567, suggesting $M_{r}=568$ and solving for $\mathrm{C}_{28} \mathrm{H}_{24} \mathrm{O}_{13}$. The ${ }^{1} \mathrm{H}$ and ${ }^{13} \mathrm{C}$ NMR spectra (Table 1), in addition to the signals associated with the aglycone apigenin, showed signals for a glucose moiety and a 3,4-dihydroxybenzoyl moiety. The deshielded nature of the ${ }^{1} \mathrm{H}$ and ${ }^{13} \mathrm{C}$ NMR signals $\left(\delta_{\mathrm{H}} 4.42\right.$ and $\left.\delta_{\mathrm{C}} 64.3\right)$ for C-6" confirmed the attachment of this 3,4-dihydroxybenzoyl moiety at C-6" of the glucose unit. Apart from the signals associated with the 3,4-dihydroxybenzoyl moiety, all other ${ }^{1} \mathrm{H}$ and ${ }^{13} \mathrm{C}$ NMR signals were comparable to published data for apigenin 7-O- $\beta$-D-glucopyranoside isolated from various plant sources (El-Ansari et al., 1991; Agarwal; Raghunath, 1989). The ${ }^{1} \mathrm{H}-{ }^{1} \mathrm{H}$ COSY 45 spectrum of 5 (Table 1) displayed ${ }^{1} \mathrm{H}-{ }^{1} \mathrm{H}$ couplings and helped to assign key proton resonances. Thus compound $\mathbf{5}$ was identified as apigenin 7-O- $\beta$-D-[6-(3,4-dihydroxybenzoyl)]-glucopyranoside (named, chrozophorin), which, to our knowledge, is a novel natural product.

Flavonoids 1, 3 and 4 have previously been reported, in trace amounts, from the aerial parts of $C$. tinctoria (Hashim et al., 1990). This is the first report on the occurrence of acacetin 7-O-rutinoside (2) in this species, and flavonoid $\mathbf{5}$ is a novel natural product. It is noteworthy that among the flavonoids (1-5) isolated in this study, flavonoids 2-5 are apigenin derivatives with glycosylation at C-7. To our knowledge, none of these flavonoid glycosides has previously been reported from any other species of the genus Chrozophora. However, a few other flavonoids, including acacetin 5-O-rutinoside, which is closely related to $\mathbf{2}$, has been reported from only a few other species of this genus (Mohamed, 2001; DNP CD-ROM, 2001; Hashim et al., 1990). From the published reports, it has appeared that most of the flavonoids found in this genus do not have oxygenation at C-3. While the family Euphorbiaceae is well known for producing various alkaloids, the distribution of flavonoids is rather limited to a few genera (ISI database, 2005; DNP CDROM, 2001).

The crude $\mathrm{MeOH}$ extract showed low levels of free radical scavenging activity (antioxidant activity) $\left(\mathrm{RC}_{50}=2.24 \times 10^{-1} \mathrm{mg} / \mathrm{mL}\right)$ in the DPPH assay (Kumarasamy et al., 2002; Takao et al., 1994). However, even this low level of activity was an indication of the presence of antioxidant compounds, which upon purification from the crude extract could show more significant activity. All flavonoids (1-5) showed prominent free radical scavenging activity. The $\mathrm{RC}_{50}$ values of the flavonoids 1-5 were found to be $\mathrm{RC}_{50}=4.38$ $\times 10^{-3} 2.26 \times 10^{-2}, 7.69 \times 10^{-4}, 8.71 \times 10^{-3}$ and $3.19 \times 10^{-4}$ $\mathrm{mg} / \mathrm{mL}$, respectively, compared to $2.88 \times 10^{-5} \mathrm{mg} / \mathrm{mL}$ for quercetin, a well-known natural antioxidant. Clearly, the novel flavonoid $\mathbf{5}$ was the most active antioxidant among the compounds, and this high level of activity could be contributed by, in addition to the flavonoid structure, the 3,4-dihydroxybenzoyl moiety. Generally, the antioxidant activity of these flavonoid glycosides, like other natural phenolic antioxidants, is a consequence of the presence of the phenolic moieties in the structures (Kumarasamy et al., 2004). The antioxidant activity of phenolic natural products is predominantly owing to their redox properties, i.e. the ability to act as reducing agents, hydrogen donors and singlet oxygen quenchers, and to some extent, could also be due to their metal chelation potential.

\section{ACKNOWLEDGEMENTS}

We thank the EPSRC National Mass Spectrometry Service Centre (Department of Chemistry, University of Wales Swansea, Swansea, Wales, UK) for CIMS analyses.

\section{REFERENCES}

Agarwal PK, Raghunath ST 1989. Carbon ${ }^{13}$ NMR of Flavonoids, Elsevier, Amsterdam.

Agrawal A, Singh J 1988. Glycosides of two xanthones and a chromone from roots of Chrozophora prostrata. Phytochemistry 27: 3692-3694.

Başlar S, Mert HH 1999. Studies on the ecology of Chrozophora tinctoria L. and Rubia tinctorum L. in Western Anatolia. Turk J Bot 23: 33-44.

Delazar A, Celik S, Gokturk RS, Unal O, Nahar L, Sarker SD 2005. Two acylated flavonoids from Stachys bombycina and their free radical scavenging activity. Die Pharmazie 11: 878-880.

Delazar A, Modarresi M, Shoeb M, Nahar L, Reid RG, Majinda RRT, Sarker SD 2006. Eremostachiin: A new furanolabdane diterpene glycoside from Eromostachys glabra. Nat Prod Res 20: 167-172.

DNP CD-ROM, 2001. Dictionary of Natural Products, Version 9:2, Chapman \& Hall/ CRC, Florida, USA.

El-Ansari MA, Barron D, Abdalla MF, Saleh NAM, Quere JLL 1991. Flavonoid constituents of Stachys aegyptica. Phytochemistry 30: 1169-1173.

GRIN Database 2006. Germplasm Resources Information Network, National Germplasm Resources Laboratory, Beltsville, Maryland. Available online at: http://www.ars-grin.gov/cgi-bin/npgs/html/ taxon.pl?400209

Hashim OK, Abouzaid MM, Abdelgalil FM, Saleh NAM 1990 The flavonoids of Egyptian Chrozophora species. Biochem Syst Ecol 18: 151-152. 
ISI Database 2005. Institute for Scientific Information, UK. Available on-line through Web of Science at: http:// wos.mimas.ac.uk/

Kumarasamy Y, Byres M, Cox PJ, Delazar A, Jaspars M, Nahar L, Shoeb M, Sarker SD 2004. Isolation, structure elucidation and biological activity of flavone Cglycosides from the seeds of Alliaria petiolata. Chem Nat Comp 40: 122-128.

Kumarasamy Y, Fergusson M, Nahar L, Sarker SD 2002. Biological activity of moschamindole from Centaurea moschata. Pharma Biol 40: 307-310.

Mabry TJ, Markham KR, Thomas KR 1970. The Systematic Identification of Flavonoids, Springer-Verlag, New York, USA.

Markham KR 1982. Techniques of Flavonoid Identification, Academic Press, London.

Markham KR, Geiger H 1993. 'H nuclear magnetic resonance spectroscopy of flavonoids and their glycosides in hexadeuterodimethylsulphoxide. In: Harborne JB (ed), The Flavonoids: Advancesin Research since 1986. Chapman and Hall, London.

Mohamed KS, Ohtani K, Kasai R, Yamasaki K 1994. Dolabellane diterpene glucosides from Chrozophora obliqua. Phytochemistry 37: 495-500.

Mohamed KS, Ohtani K, Kasai R, Yamasaki K 1995. 3Hydroxy-3-methylglutaryl dolabellane diterpenes from Chrozophora obliqua. Phytochemistry 39: 151-161.

Mohamed KS 2001. Phenylpropanoid glucosides from Chrozophora obliqua. Phytochemistry 58: 615618.

Nahar L, Russell WR, Middleton M, Shoeb M, Sarker SD 2005. Antioxidant phenylacetic acid derivatives from the seeds of Ilex aquifolium. Acta Pharma 55: 187193.

Nahar L, Sarker SD 2005. Chenoalbuside: an antioxidant phenolic glycoside from the seeds of Chenopodium album L. (Chenopodiaceae), Rev Bras Farmacogn 15: 279-282.

Phytochemical and Ethnobotanical Databases 2005. Green Farmacy Garden, Murphy Road, Fulton, MD 20759. Available on-line at: http://www.ars-grin.gov/duke/

Sarker SD, Shaheen EM, Eynon E, Nahar L 2005a. Caffeic acid decyl ester: an antioxidant principle from Phleum pratense (Poaceae). Chem Nat Comp 41: 293-296.

Sarker SD, Kumarasamy Y, Shoeb M, Celik S, Yucel E, Middleton M, Nahar L 2005b. Antibacterial and antioxidant activities of three Turkish species of the gemus Centaurea. Oriental Pharmacy and Experimental Medicine 5: 246-250.

Takao T, Watanabe N, Yagi I, Sakata K 1994. A simple screening method for antioxidants and isolation of several antioxidants produced by marine bacteria from fish and shellfish. Biosci Biotech Biochem 58: 17801783 